についてはな⿰ $10 \%$ 課税されているので，引続き，

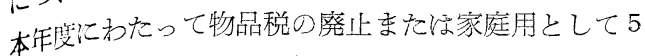
合以上のるのについて高無税といら方針で猛烈な運動 繶けていている。

b) 企業合理化の問題槐法嚗の製造方法法，中

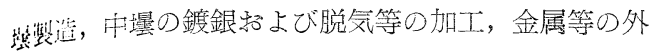
装㞦，最終的な中嚗と外装の組立等の4工程に分れ

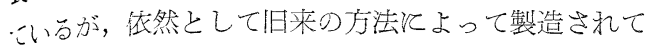
い台た的；合理化が強く要望されていたが，日本工業

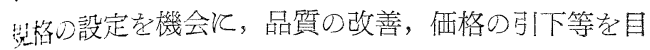
糹して合理化に乘り出すとととなった。

すな⿰七，本年度はすず真空装置の自動機化に着手 亏っことになり，全国魔法摆協同組合の共同事業とし

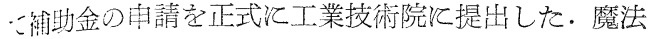
罢業界で症現在 18 社が工場指定を受故て規格品の製 濰に努才しているが，さらに工場指定在希望している 場も二，三娄り，引続いてその他の製造工程の自動 化，または改善に努力することにより，国内はもらろ ん，海外市場の拡大を目指している。な杼電気熔解の 【業化，ガラス管より製造する錠剤嚗执よび薬摆等の て業化は本年度の課題であらう。

c) 計量法による容量検査計量法による容量検 萑命が今国会起通過したため, 酒嚗, 醬油嚗等を始め として透明, 半透明で液体を入れる容器については容 恰査唯行われることになった。今のところでは強制 されるものでなく，需要者側加らの要求があった場 会限られている。
通産省当局の方針としては，業界の意向妇考慮し て，一定の基準により指定工場制党採用し，1本 1 本 の容量検査をすることなく，その工場で指定された容 器を製造した場合及許可する模様である。指定される 工場の基準は, 現在のところ自動製嚗工場を対象とし て扮り，容量检査の公差等も自動機製品を採用してい るから, 差当りぼ自動機関係の製品から採り上げられ る見込みである。

しかし, 順次容量検查の対象となっていく時, やが ては半自動製品もその対象となるので，この点につい て先般関係当局と㴧談会を開いた。当局と乙ては，差 当りは，自動製品のものから採りあげ，中小工場には 余り影響の招よばない方針で指導する由だが，関係業 界はとれを他山の石とせず，やがて来るべき事態を予 想して徐々にとの対策を樹てるべきである。

\section{むす ず}

30 年の生産は2 9 年に比べてかなり堅実な様相を示 して秎り，31 年はさらに業界の健全な歩みが数字に よって立証されることと思われるし，ま光，ての事実 を期待しているものである・最近のヨーロッパ各国の ガラス製品の生産方式は，アメリカの大規模なとれよ りも，さらに小規模なものであり，日本の現在のとれ よりもさらに小規模な工場が多数あって, 消費市場に 見合った生産を続けている由である。

（日本硝子製品工業会 長藤 清）

\section{珐瑯 鉄 器}

\section{I. 珐瑯工場の分布}

本邦珐瑯鉄器工場の地域別分布状沅をみると下記の 通りである。

\begin{tabular}{|c|c|c|c|c|c|}
\hline 地 & 区 & 別 & $\begin{array}{l}\text { 䜽出向工場 } \\
\text { 地向王場数 }\end{array}$ & $\begin{array}{l}\text { 化学容器 } と \text { 多ン } \\
\text { 繁造工数 }\end{array}$ & 合 計 \\
\hline & 大 阪 & 府 & 22 & 1 & 23 \\
\hline 酻 & 兵＼cjkstart庫 & 県 & 2 & 4 & 6 \\
\hline & 三 重 & 県 & 2 & 1 & 3 \\
\hline & 愛 知 & 晾 & 2 & 1 & 3 \\
\hline & 福＼cjkstart岡 & 県 & 2 & 1 & 3 \\
\hline & 宩＼cjkstart京 & 都 & 24 & 2 & 26 \\
\hline 莫 & 神寮川 & 県 & 1 & 0 & 1 \\
\hline & 琦 丙 & 県 & 2 & 2 & 4 \\
\hline & 群 馬 & 県 & 1 & 0 & 1 \\
\hline & 合 & 詮 & 58 & 12 & 70 \\
\hline
\end{tabular}

\section{II. 輸出 状 況}

本年度の翰出額は約 166,000 万円，461 万ドルで前
年度 553 万ドルル比して $16 \%$ の減少で岀った。出荷 栶数は 125,388 梱で前年度の 154,108 梱より 28,720 棝の減少，比率で $18.6 \%$ の低下である.

これを仕问地別にすると下表の通りである。

順位についてはアフリカ市煬が前年同様に第1位を 占わたが，金額は 325,677 干円，图数は 21,420 の減 少となった。1 相当りの指数电前年度 14,156 円から 13,733 円と433 円方安く3\%減となった。これば珐 輸出統計 $(\mathrm{A})$

\begin{tabular}{|c|c|c|c|c|c|c|c|}
\hline \multirow[b]{2}{*}{ 順位 } & \multirow{2}{*}{\multicolumn{2}{|c|}{ 仕 向 }} & \multirow{2}{*}{\multicolumn{2}{|c|}{ 向 地 }} & \multirow{2}{*}{$\begin{array}{l}\text { 金 額 } \\
\text { (千田) }\end{array}$} & 比 & 率 \\
\hline & & & & & & $\begin{array}{c}\text { 本年度 } \\
(\%)\end{array}$ & $\begin{array}{c}\text { 前年度 } \\
(\%)\end{array}$ \\
\hline 1 & $\gg$ & フ & リ & カ & 730,135 & 44.0 & 53 \\
\hline 2 & 近 & 果 & 諸 & 国 & 264,409 & 16.0 & 11. \\
\hline 3 & 夕 & & & 1 & 257,463 & 15.5 & 7 \\
\hline 4 & ? & v & & - & 130,294 & 8.0 & 6 \\
\hline 5 & 中 & 南 米 & 諸 & 国 & 81,813 & 5.0 & 7 \\
\hline 6 & 仏 & & & 印 & 60,048 & 3.6 & 1 \\
\hline 7 & 1 & ンドオ & ネ之 & & 58,608 & 3.5 & 6 \\
\hline 8 & ピ & u & & $\checkmark$ & 36,208 & 2.0 & 6 \\
\hline 9 & フ & $\begin{array}{l}1 \\
1\end{array}$ & $ヒ^{\circ}$ & ン & 8,495 & 0.5 & 1 \\
\hline 10 & パ & 丰 ス & 夕 & ע & 8,430 & 0.5 & 0 \\
\hline & z & a & & 他 & 24,197 & 1.4 & 2 \\
\hline 合 & & & & 計 & $1,660,100$ & 100.0 & 100 \\
\hline
\end{tabular}


輸出統計 (B)

\begin{tabular}{|c|c|c|c|c|c|c|c|c|}
\hline \multirow[b]{2}{*}{ 順位 } & \multirow{2}{*}{\multicolumn{5}{|c|}{ 仕 尚 地 }} & 出荷梱数 & 比 & 率 \\
\hline & & & & & & （栶） & $\begin{array}{c}\text { 本年度 } \\
(\%)\end{array}$ & $\begin{array}{c}\text { 前年度 } \\
(\%)\end{array}$ \\
\hline 1 & $\boldsymbol{P}$ & フ & & y & 力 & 53,164 & 42 & 48 \\
\hline 3 & 近 & 東 & & 锗 & 国 & 17,021 & 14 & 11 \\
\hline 2 & 夕 & & & & 1 & 21,063 & 17 & 9 \\
\hline 4 & $\checkmark$ & & $v$ & & - & 10,535 & 8 & 7 \\
\hline 5 & 中 & 南 & 米 & 諸 & 国 & 7,869 & 6 & 9 \\
\hline 7 & 仏 & & & & 印 & 4,512 & 4 & 1 \\
\hline 6 & 1 & ン & ド & $i$ & $r$ & 4,636 & 4 & 7 \\
\hline 8 & ビ & & ル & & $\checkmark$ & 2,876 & 2 & 6 \\
\hline 9 & 此 & & & & 島 & 870 & 1 & 1 \\
\hline 10 & パ & キ & z & 夕 & ン & 746 & 1 & 0 \\
\hline$\tau$ & & の & & & 他 & 2,096 & 1 & 1 \\
\hline 合 & & & & & 計 & 125,388 & 100 & 100 \\
\hline
\end{tabular}

瑯鉄器の最大市場であるナイゼリア，ゴールドコース トに和ける香港製品の安值乱売の結果，市場の混乱と 共に現われた日本製品への影響である．香港製品の進 出が東アフリカを完全に席捲し，現在でも西アフリカ に上記のような問題が出てくることは，ライセンス問 題, 価格の低廉と同市場の常時視察, 積極的な活動と 品質の向上，価格の維持のために輸出調整組合に括け る生産制限と後退している現状の日本製品が，今後如 何にして行くかは重要課題である.

第 2 位の近東諸国はアデン，イラク，イラン，クエ イト，アラビアの諸国で金額 42,750 千円，485 梱の 増加, 価格指数も $16 \%$ とあがり, 前年度に引続いて 好調にあるのはほとんどの製品が給付であるので，日 本製品のデザインの特色が香港製品を押さえて充分に 発揮している。

第 3 位はタイ国で, 従来から三大市場の一つと重要 視されている所である.前年度は 4 位であったが金額 113,157 千円，7,488 梱と増加し，価格指数は $13 \%$ 上昇した。同市場はヨーロッパ製品，香港製品，日本 製品の販売激戦場であるだけと本年度の増量，価格高

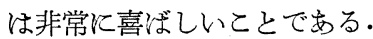

第 4 位はマレーで金額は 8,375 干円，105 相の増加 であるが，価格指数は $6 \%$ の上昇を見た. 近年東南ア ジアの輸出が減少している時, 充分にこれらタイ, マ レーの市場を調查して伸長さす必要がある・

第 5 位は中南米諸国でヴェネズェラ，エクアドル， キューバ，パナマ，コスタリカ，ニカラガ等である. 前年の 3 位から転落し，金額も 65,806 千円，5,806 梱と減少した. 自然価格指数を $4 \%$ 方下落した.

第 6 位仏印々 前年 8 位より躍進して金額8 42,644 千円， 2,873 图と増加した. 価格指数も25\%上昇し， 今後の輸出に期待がかけられる。

第 7 位イドネシアは前年より金額 69,509 千円， 5,665 梱と大巾に減少した.これはインドネシア向に は輸出ライセンスを調整されているためである・それ

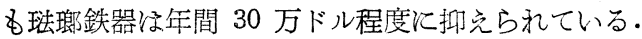
昭和 25 年, 26 年頃は月平均 50 60 万ドルも輸出さ
れた最大市場であったが，対日ライセンスの強化のた め, ジャカルタに香港系の珐瑯工場が 1 社設立された ということであるが, 工場の生産量では $1 / 10$ の需要も 充足することは出来ないであろう．価格指数は $2 \%$ 高 である。

第 8 位ビルマは金額 74,873 千円，4,729 相も減少 した。これらは対日ライセンスが現在のところ，スト ップのためである. 価格指数も変動なく多少上昇気味 である・

第 9 位比島は金額で 4,649 千円減少した．これは比 島に珐瑯工場があり，珐瑯鉄器の需要は自給体制にな りつつあるので，これが供給には特殊製品と特殊絵付 等の技術的高級製品が輸出されている状態である.

第 10 位はパキスタンで金額 5,515千円，1,865 相 の増加であるが，近年カラチに珪郎工場が設置されて 年々輸出量が減っていたが，日本製品の特色が表面化 して来たと思われる. その他珐瑯鉄器の輸出先は香港 (これはタイとインドネシアにスイッチされる), 沖 繩， ヨーロッパ，北アメリカ・カリフォルニア州，南 洋群島, 太洋州, インド, セイロン, 朝鮮であった. 価格指数も原材料高が反映して輸出量は著しく低下し たが，前年度より $2.5 \%$ 高に増加した。

品種別生産実績

\begin{tabular}{|c|c|c|c|c|c|c|}
\hline \multirow[b]{2}{*}{ 順位 } & \multirow{2}{*}{\multicolumn{3}{|c|}{ 品 名 }} & \multirow{2}{*}{$\begin{array}{l}\text { 金 額 } \\
\text { (千円) }\end{array}$} & \multirow{2}{*}{$\frac{\text { 比 }}{\begin{array}{c}\text { 本年度 } \\
(\%)\end{array}}$} & \multirow{2}{*}{$\frac{\text { 率 }}{\begin{array}{c}\text { 前年度 } \\
(\%)\end{array}}$} \\
\hline & & & & & & \\
\hline 1 & 洗 & 面 & 器 & 387,585 & 22.6 & 26.3 \\
\hline 2 & ボ & $-U$ & 類 & 373,247 & 22.5 & 21.2 \\
\hline 3 & $卜$ & $v$ & - & 208,178 & 12.5 & 13.2 \\
\hline 4 & プ & $v-1$ & 類 & 195,454 & 11.8 & 12.1 \\
\hline 5 & 弁 & 当 & 箱 & 97,909 & 6.0 & 5.2 \\
\hline 6 & 力 & ル ド ロ & ン & 84,308 & 5.1 & 4.2 \\
\hline 7 & 茶 & 瓶 & 類 & 80,708 & 4.9 & 4.7 \\
\hline 8 & $\overrightarrow{フ ゙}^{\prime}$ & $1 \% V=$ & 類 & 61,160 & 3.7 & 5.4 \\
\hline 9 & 匙 & & & 43,129 & 3.0 & 2.4 \\
\hline 10 & ソ & 一スパ & ン & 14,676 & 1.0 & 0.6 \\
\hline 11 & チャ & マンパーポッ & 卜 & 12,066 & 0.8 & 1.0 \\
\hline 12 & $\checkmark$ & ッ & $\mathscr{Y}$ & 10,773 & 0.7 & 0.7 \\
\hline 13 & 七 & - $ト$ & 類 & 10,762 & 0.7 & 0.4 \\
\hline 14 & i & $f=-$ & 類 & 9,136 & 0.5 & \\
\hline 15 & オ & ー ハルトV & - & 8,756 & 0.5 & \\
\hline & そ & の & 他 & 62,253 & 3.6 & \\
\hline 合 & & & 計 & $1,660,100$ & 100.0 & \\
\hline
\end{tabular}

\section{III. 輸出珐瑯鉄器調整組合の現況}

1) 組 合 員

関東 1 , 中部 2 , 近畿 22 , 九州 2 , 合計 25

\section{2）焼成炬設備}

石炭と重油哣 78 基, 箱型電気炉 19 基, 廻転電気 炤 15 基, 合計 112 基
3) 絵付設 備
木枠 446 箇
4) 基準数量 202,472 相
5)生産数量 118,806 "

亿, 普通生 産 数 113,961 梱 


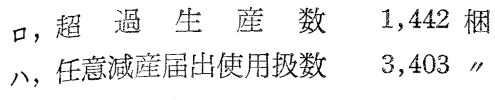

\section{IV. 内 需 状 況}

斑㰾鉄器の生産状況多輸出向は香港，ヨーロッパ製 品等の激烈なる販売競争のために, 採算状洗凷次第に 悪化し，原材料高の製品安の現象となり，洒格の低下

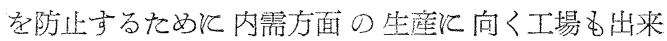
て, 翰出品上同様品種である洗面器, キャッシボー ル，茶瓶，コーヒポット等が販売されている。な特， 内需向として特殊製品（パーコレータ，キッチンセッ ト等) 新製品の販売も研究されている。他にバット， 看板，医療器具等飞生産されている。

(日本珐瑯工業会)

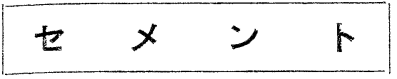

はしがき

わが国のセメント工業は炤和 26 年頃より数年間に わたって非常な好況そ持続していたが，その後内外の 蕌情勢が国際的にふスターリンの死亡によってマレン コフォよびブルガーニン政権の全画的平和攻勢が行わ れて世界的な軍桩体制が緩慢化し，国内的に消費 ンフレの抑王と国際収支の改善孛はかるべく政府はデ フレ政策をとり，剘政投融資を大円に削減すると共に

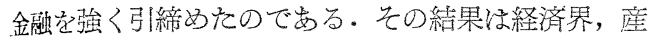
業界に大きな影響を括よぼし，デフレの様相に漸次深 刘てなり種々な問題を生じたのであるが，昭和 29 年 加 30 年にかけてのこのデフレ政策により企業の経 営と金融胫著しく正常化し，1955 年の後半頃より世 界景気の好転に伴いわが国の輸出貿易《大いに伸張 し，また好天に惠采れた米作は未曽有の大豊作となっ てわが国の各方面潮次明かるさをとりもですよう になって来たことは周知の通りである。

このよう汇変転する内外の諸情勢の下に和ける炤和 30 年 (歴年) のセメント工業は一体如何なる推移を迻 ったであららか。以下，その事情てついて少しく記述 してみよう・

彷来比較的に一般景気の動向に遅れて影響を蒙むる わがセメント工業は，昭和 29 年前羊までは比較的順

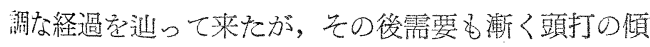
向が現われてセメント価格面にも特よび，29年10月 頃より下降を歹るようになり，30 年炕入り 3 月以降

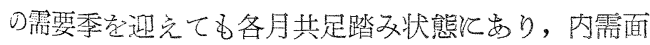
で前年の29 年度を下廻台結果となってしまった。 ただ， 30 年には輸出の好調が後半から続いたので， 全体としては前年度程度の販売害績を挙げ得たのであ る・しかしながら，一方セメントの生産設備は老柯化 せるものの更新を含导とはいえ大币に増強せられたの である・したがって，れメント業全体としてみると艺 の操業度は昭和 25 年が $69.1 \%$ ，26 年が $80.9 \%$ ， 27 年は $79.2 \%, 28$ 年は $88.6 \%, 29$ 年は $91.2 \%$ と
なっているが，30 年ね76.6\% と急潡な低下をみるよ らになったのである・したがって, 戦後 10 年上昇一 路のセメントも頭打からその設借面に過剩が云々せら れるようとなった。

\section{I. 需 要 概 況}

a) 生座設備昭和 29 年末に怙ける全国セメン ト工場の保有回転䈍 16 社 37 工場 108 基で月産能力 は 1,055,400トンであったが，丁度1ケ年後の30 年 12月末でほ 18 社 42 工場 119 基, 月産能力 $1,200,100$

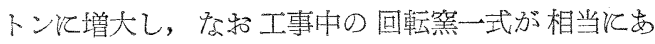
る・すなわち 30 年中新設せられた工場を見ると電 気化学工業青梅工場 ( 1 基)，三菱セメント黑崎工場 ( 2 基), 富士セメント室蘭工場 (粉础のみ), 日本セ メント埼玉工場（ 2 基），宇部興産伊佐工場（ 2 基） と秩父セメ゙ント第二工場 2 基吕 3 月試運転を開始す る状態である・かくして 31 年3月末でね 125 基とな って月産 130 万トンのセメント基給能力が保有せらる るょうれなり，官治統制の撤廃をみた昭和 25 年頭初 からみると奏に 2 倍以上となる。今，この生産能力を 䛧区别に多と次の通りである。

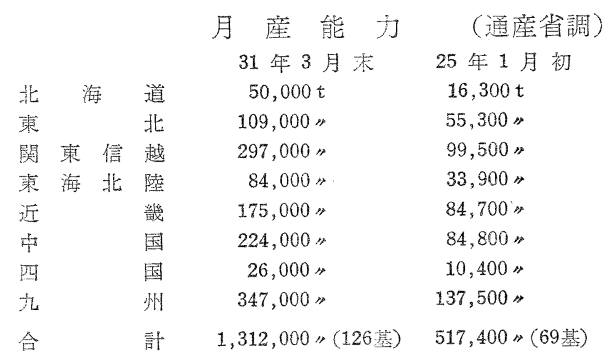

以上のよう飞関東信越地区を箨頭飞各地区共とれぞ れ2倍から3倍にまで増加をみた訳であり，しか子増 加せられた設備は近代的新釦設備であり，その能率の 点では旧式のものに比し頗る優否であり，長期連続運 転が可能であるからセメントの供給力の点については 何らの心配々いらない。

b) 生産概況 昭和 25 年当時は年間 445.1 万卜 ン程度であっ祭セメントの生産高も， その後逐年增加 して29 年度に後半若干の低下安った过年間 攸通ずると 1,064 万トンと 2 倍以上に増加し，戦前戦 